descriptions of vaccinia, and in the present case vaccination both in infancy and in adulthood was followed by acute diarrhoea. (According to the hospital notes relating to the episode in infancy no intestinal pathogen was isolated.) The symptom may have been a nonspecific intestinal reaction to a constitutional phase of the illness, but Gurvich et $a l^{4}$ isolated vaccinia virus from the pharynx of 18 out of 80 children three to 20 days after vaccination, and it seems possible that the virus itself may sometimes reach the gastrointestinal tract. Accidental vaccinia may follow the transfer of infected material from the patient himself, or from another who has been recently vaccinated. In the present case transmission was probably by the fingers to a perianal region excoriated by diarrhoea. In the treatment of accidental vaccinia in infants, especially when there is evidence of a toxic reaction the administration of vaccinia immune globulin (VIG) has been recommended. ${ }^{5}$

I thank Dr Helen Mair for confirming the diagnosis, and Dr T M Pollock for helpful comments.

${ }^{1}$ Lane, J M, et al, New England fournal of Medicine, 1969, 281, 1201.

${ }^{2}$ Christie, A B, Infectious Diseases. Epidemiology and Clinical Practice, 2nd edn, p 242. London, Churchill, 1974.

${ }^{3}$ Berkowitz, J, American fournal of Surgery, 1953, 86, 549.

${ }^{4}$ Gurvich, E B, et al, fournal of Hygiene, Epidemiology, Microbiology and Immunology, 1974, 18, 69.

${ }^{5}$ Goldstein, J A, et al, Pediatrics, 1975, 55, 172.

Student Health Service, Leicester LE2 6BF

J L CRIGHTON, MB, CHB, director

\section{Diet and diuretics in pregnancy and subsequent growth of offspring}

Campbell and MacGillivray ${ }^{1}$ studied the effect of weight reduction in the last ten weeks of pregnancy on the incidence of pre-eclampsia in primigravidae gaining more than $570 \mathrm{~g}$ a week between 20 and 30 weeks of gestation. One group received two tablets of Navidrex $\mathrm{K}$ (cyclopenthiazide $250 \mu \mathrm{g}$, potassium $600 \mathrm{mg}$ ) daily, and another a 5 -MJ (1200 k-cal) diet. A third, untreated group acted as controls. The patients were matched for social class, cigarette smoking, age, height, and weight for height at 20 weeks of gestation. When pregnancies complicated by pre-eclampsia were excluded the birth weight of the children of the untreated mothers was found to be greater than that of the children of mothers in either of the treated groups.

The subsequent growth of 61 of the children is reported here.

\section{Patients, methods, and results}

The 61 mothers had been normotensive throughout pregnancy; 17 were in the diuretic group, 22 in the dieted group, and 22 in the untreated group. Because of the wide age range of the children (3.8-5.7 years) all measurements

Distribution of centiles among the 61 children

\begin{tabular}{|c|c|c|c|c|c|c|}
\hline & & & Centile & $\begin{array}{l}\text { Diuretic } \\
\text { group } \\
(\mathrm{n}=17)\end{array}$ & $\begin{array}{l}\text { Dieted } \\
\text { group } \\
(\mathbf{n}=22)\end{array}$ & $\begin{array}{c}\text { Untreated } \\
\text { group } \\
(\mathrm{n}=22)\end{array}$ \\
\hline Weight & $\cdots$ & . & $\begin{array}{l}0-50 \\
>50\end{array}$ & $\begin{array}{r}3 \\
14\end{array}$ & $\begin{array}{c}9 \cdot 5 \\
12 \cdot 5^{*}\end{array}$ & $\begin{array}{r}4 \\
18\end{array}$ \\
\hline Height & .. & $\cdots$ & $\begin{array}{l}0-50 \\
>50\end{array}$ & $\begin{array}{r}4 \\
13\end{array}$ & $\begin{array}{l}10 \\
12\end{array}$ & $\begin{array}{r}4 \\
18\end{array}$ \\
\hline \multicolumn{2}{|c|}{ Head circumference } & . & $\begin{array}{l}0-50 \\
>50\end{array}$ & $\begin{array}{c}4 \cdot 5 \\
12 \cdot 5 *\end{array}$ & $\begin{array}{l}11.5 \\
10.5 \dagger\end{array}$ & $\begin{array}{l}12 \\
10\end{array}$ \\
\hline
\end{tabular}

* One value on 50 th centile.

tThree values on 50 th centile. were plotted on the appropriate centile charts ${ }^{2} 3$ (HCB 18, HCG 19; Creaseys Ltd) before the three groups were compared. All measurements were made by me. Children were weighed on a beam balance in their underclothes. Head circumference was measured with a tape measure, and height with the Harpenden Stadiometer. Each mother was sent a tape measure and instructions on how to record her husband's height. The height of each child was related to mean parental height on a centile chart ${ }^{2}$ designed for this purpose.

The table gives the results. The children of mothers in the dieted group weighed less than those of mothers in either the untreated or diuretic group $(P<0.05)$. Similarly when height was adjusted for mean parental height the children of mothers in the dieted group were shorter than those of mothers in the other two groups $(P<0.05)$. Head circumferences of children in the diuretic group were greater than those in the dieted and untreated groups $(P<0.05)$. The distribution of weight and height of the children in the dieted group was similar to the standards, ${ }^{23}$ while the children in the untreated and diuretic groups were significantly heavier than the standard $(P<0.01)$ and both groups were significantly taller than the standard $(P<0.01$ and $\mathrm{P}<0.05$ respectively).

\section{Comment}

It is well known that a persisting size deficit occurs in prenatally undergrown humans and animals. ${ }^{4}$ This study suggests that dietary restriction of women with excessive weight gain in pregnancy not only impairs fetal growth but results in a persistent size deficit in the height and weight of the offspring. Whether this effect is harmful or beneficial is uncertain, but it should be borne in mind when dietary restriction in pregnancy is recommended.

I thank Dr Doris Campbell and Professor Ian MacGillivray for permission to undertake this study, and Dr George Russell for advice.

1 Campbell, D M, and MacGillivray, I, British fournal of Obstetrics and Gynaecology, 1975, 82, 572 .

2 Tanner, J M, Goldstein, H, and Whitehouse, R H, Archives of Disease in Childhood, 1970, 45, 755.

3 Tanner, J M, Whitehouse, R H, and Takaishi, M, Archives of Disease in Childhood, 1966, 41, 454.

4 Gruenwald, P, The Placenta. Lancaster, Medical and Technical Publishing, 1975.

\section{Department of Child Health, University of Aberdeen, Aberdeen} AB2 2ZD

I BLUMENTHAL, MRCP, DCH, registrar (present address: Department of Neonatology, Cook County Hospital, Chicago, USA)

\section{Immunoreactive beta-melanocyte- stimulating hormone and melanin pigmentation in systemic sclerosis}

Skin pigmentation is a common feature of systemic sclerosis and may resemble that seen in Addison's disease. Previously we showed that the increased plasma $\beta$-melanocyte-stimulating hormone concentrations in chronic renal failure ( $\beta-\mathrm{MSH})$ are due to impaired renal metabolism of the hormone, ${ }^{1}$ and we wondered whether the decreased renal plasma flow that occurs in systemic sclerosis ${ }^{2}{ }^{3}$ might similarly impair renal metabolism of $\beta-\mathrm{MSH}$ and thereby explain the pigmentation in the disease.

\section{Patients, methods, and results}

Sixteen patients with systemic sclerosis were studied, of whom six showed moderate to severe pigmentation, and plasma $\beta-M S H$ was measured with a modification of the method of Thody and Plummer. ${ }^{4}$ Renal function had been studied several years earlier in 11 of these patients ${ }^{3}$ and some impairment of renal blood flow, but not of glomerular filtration, had been found. No recent studies of renal function had been made but the blood urea concentration was normal in all.

The mean plasma $\beta$-MSH level in the patients with systemic sclerosis was $14 \cdot 4 \pm \mathrm{SE} 2 \cdot 9 \mathrm{ng} / \mathrm{l}$, compared with $16 \cdot 2 \pm 1 \cdot 2 \mathrm{ng} / 1$ in 55 normal controls. 


\section{Comment}

This finding clearly shows that a raised plasma $\beta-\mathrm{MSH}$ level is not the cause of the pigmentation in systemic sclerosis. Although we did not measure the para-aminohippurate clearance in our patients, a decreased renal blood flow had been found in most of those in whom it was measured several years earlier; we therefore surmise that decreased renal blood flow does not impair renal metabolism of $\beta-\mathrm{MSH}$. This supports our parallel evidence from post-transplantation studies $^{5}$ that access to the renal tubule of $\beta-M S H$ undergoing catabolism is by tubular absorption after glomerular filtration of the peptide and not by delivery from the peritubular vasculature.

\section{Smith, A G, et al, British Medical fournal, 1976, 1, 874.}

2 Urai, L, et al, British Medical fournal, 1958, 2, 1264

${ }^{3}$ Marks, J, and Holti, G, Annales de Dermatologie et de Syphiligraphie, 1972, 99, 281.

4 Thody, A J, and Plummer, N A, fournal of Endocrinology, 1973, 58, 263.

${ }^{5}$ Smith, A G, et al. Paper in preparation.

Department of Dermatology, University of Newcastle, Newcastle upon Tyne NE1 4LP

A G SMITH, MB, MRCP, senior registrar

G HOLTI, MD, FRCP, consultant dermatologist

SAM SHUSTER, PHD, FRCP, professor of dermatology

\section{Hypercalcaemic phaeochromocytoma}

The occasional occurrence of hypercalcaemia in phaeochromocytoma is usually due to coexisting primary hyperparathyroidism as part of a multiple endocrine tumour. In four recent cases of phaeochromocytoma the hypercalcaemia, unlike that of patients with a polyendocrine neoplasia, subsided after the catecholamine-secreting tumour was removed. ${ }^{1-4}$ We describe here a patient with a noradrenaline-secreting phaeochromocytoma whose associated hypercalcaemia was corrected by removal of the tumour.

\section{Case report}

A 45-year-old miner was admitted to hospital on 28 September 1975 for evaluation of severe hypertension and mild diabetes mellitus. An episode of macroscopic hematuria two months earlier had led to the discovery of a renal stone in the right pelvis. Over the past six months the patients had lost 11 $\mathrm{kg}$ in weight. Treatment on admission consisted of glipizide $2.5 \mathrm{mg} / 24 \mathrm{~h}$ and debrisoquine $20 \mathrm{mg} / 24 \mathrm{~h}$. No diuretic had been given.

On examination the patient was pale and sweating. The pulse was $104 / \mathrm{min}$ and blood pressure was $200 / 123 \mathrm{~mm} \mathrm{Hg}$ supine and $200 / 120 \mathrm{~mm} \mathrm{Hg}$ standing. The severity of the hypertension was shown by left ventricular hypertrophy noted both on electrocardiogram and chest radiograph and by a KeithWagener stage- 3 retinopathy.

Serum electrolytes and renal function were normal. Twenty-four hour proteinuria was raised at $1.09 \mathrm{~g}$. Microscopical examination of the urine sediment disclosed 100-120 red blood cells and 100-120 white blood cells per high power field. Urine culture was sterile. Glucose tolerance was decreased; insulin response was raised and delayed. Serum calcium levels, determined on four different days, were slightly but consistently raised (see table). Serum alkaline phosphatase levels, 24-hour urinary calcium, bone radiography, and parathyroid hormone blood level were normal. Adrenocortical and thyroid function were normal. Urinary excretion of free catecholamines, noradrenaline, total metanefrines, and vanillylmandelic acid were about 10 times higher than normal, whereas adrenaline excretion was within normal limits (see table).

A right suprarenal tumour measuring $3 \times 6 \mathrm{~cm}$ was disclosed by renal and adrenal arteriography and removed on 22 October 1975 (weight $30 \mathrm{~g}$ ). Histological examination showed a benign phaeochromocytoma. The catecholamine concentration in the tumour was $1176 \mu \mathrm{g} / \mathrm{g}$ for noradrenaline and $53.1 \mu \mathrm{g} / \mathrm{g}$ for adrenaline.

Blood pressure and catecholamine excretion returned progressively to normal within eight days after surgery. The serum calcium level, determined on four different days, and glucose tolerance became normal. Serum albumin and total protein concentrations were normal both before and after operation. Urinary cyclic adenosine monophosphate excretion remained normal.

The patient was discharged on 8 November 1975. The blood pressure remained normal up to a month later, when the patient died suddenly at home after complaining for a few minutes of an excruciating transthoracic pain.

\section{Discussion}

The cause of hypercalcaemia associated with phaeochromocytoma but unrelated to coexisting primary hyperparathyroidism remains a moot point. Gray and Gillon ${ }^{4}$ have suggested that catecholamines stimulate the release of parathyroid hormone. Alternatively, Finlayson and $\mathrm{Casey}^{3}$ have proposed that hypercalcaemia results from a direct action of catecholamines on bone cyclic adenosine monophosphate production. These two hypotheses are tenable in the presence of adrenaline-producing phaeochromocytomas, as both parathyroid hormone release from parathyroids and bone adenylcyclase are stimulated mainly by adrenaline but little by noradrenaline.

Sufficient data to test this hypothesis are available in only one patient, ${ }^{2}$ who excreted mainly noradrenaline whereas adrenaline output was only slightly raised. In our patient adrenaline excretion was normal and adrenaline concentration in the tumour was strikingly reduced, the main abnormality being confined to noradrenaline production. It thus seems unlikely that hypercalcaemia resulted from a direct or indirect action of adrenaline, a conclusion substantiated by the observation of Miller et $a l^{5}$ that three patients with adrenalinesecreting phaeochromocytomas did not have hypercalcaemia. Other explanations, perhaps implicating increased prostaglandin secretion by the tumour, ${ }^{4}$ should therefore be proposed.

We thank Dr R Bouillon for estimating parathyroid hormone levels and Professor A De Schaepdrijver for measuring the catecholamine concentration in the tumour.

${ }^{1}$ Swinton, N W, jun, Clerkin, E P, and Flint, L D, Annals of Internal Medicine, 1972, 76, 455.

${ }^{2}$ Kukreja, S C, et al, Annals of Internal Medicine, 1973, 79, 838.

${ }^{3}$ Finlayson, J F, and Casey, J H, Annals of Internal Medicine, 1975, 82, 810.

+ Gray, S R, and Gillon, J, British Medical fournal, 1976, 1, 378

${ }^{5}$ Miller, S S, et al, Annals of Internal Medicine, 1975, 82, 372.

Renal Unit, Department of Medicine, Cliniques Universitaires StPierre, University of Louvain, Louvain, Belgium

J F DE PLAEN, chef de clinique adjoint

F BOEMER, resident

C VAN YPERSELE DE STRIHOU, professor of medicine

Blood pressure and urinary catecholamine, calcium, and parathyroid hormone levels before and after resection of phaeochromocytoma

\begin{tabular}{|c|c|c|c|c|c|c|}
\hline & $\begin{array}{c}\text { Blood pressure } \\
(\mathrm{mm} \mathrm{Hg})\end{array}$ & $\begin{array}{c}\text { Free catecholamines } \\
(\mu \mathrm{g} / 24 \mathrm{~h})\end{array}$ & $\begin{array}{l}\text { Noradrenaline } \\
(\mu \mathrm{g} / 24 \mathrm{~h})\end{array}$ & $\begin{array}{l}\text { Adrenaline } \\
(\mu \mathrm{g} / 24 \mathrm{~h})\end{array}$ & $\begin{array}{l}\text { Calcium } \\
(\mathrm{mmol} / \mathrm{l})\end{array}$ & $\begin{array}{l}\text { PTH } \\
(\text { ng/l) }\end{array}$ \\
\hline Normal range: & & $10-90$ & $10-80$ & $2-15$ & $2 \cdot 2-2 \cdot 6$ & $0-400$ \\
\hline $\begin{array}{l}3 \text { October } 1975 \\
6 \text { November } 1975\end{array}$ & $200 / 125$ & $918 \cdot 6$ & $909 \cdot 3$ & $9 \cdot 3$ & $\begin{array}{l}2.70 \\
2.67 \\
2.70 \\
2.67 \\
2.35 \\
2.48 \\
2.53 \\
2.45\end{array}$ & 210 \\
\hline
\end{tabular}

